\title{
INFLUENCE OF CASHEW STEAMING ON THE QUALITY ATTRIBUTES OF CASHEW-PAWPAW MIXED FRUIT JUICE
}

\author{
${ }^{* 1}$ Bolarinwa, I. F., ${ }^{2}$ Aruna, T. E., ${ }^{3}$ Abioye, A. O. and ${ }^{1}$ Adelakun, O. E. \\ 1Department of Food Science, Ladoke Akintola University of Technology, \\ Ogbomosho, Nigeria
}

2Department of Food Science and Technology, Kwara State University, Kwara State, Nigeria

${ }^{3}$ Department of Food Engineering, Ladoke Akintola University of Technology, Ogbomosho, Nigeria

*Corresponding Author: ifbolarinwa@lautech.edu.ng

\section{ABSTRACT}

Cashew is a tree crop that is valued for its nuts, with the fleshy fruits (cashew apple) receiving little attention due to its high acidity. In this study, ascorbic acid, total solid, total soluble solid, $\mathrm{pH}$, titratable acidity and microbial stability of cashew-pawpaw juice prepared by mixing varying proportions (90:10, 80:20, $70: 30,60: 40,50: 50)$ of raw or steamed cashew and pawpaw puree were evaluated. Increased in ascorbic acid (10.20-23.96 mg/100 g), total solid (8.03$12.37 \%)$, total soluble solid (1.37-3.5\%) and $\mathrm{pH}(3.68-4.65)$ were recorded for the cashew-pawpaw juice samples. The titratable acidity (TTA) of the juice samples decreases $(0.39-0.19 \%)$ with increasing amount of pawpaw puree in the juice blends. Total yeast and total coliform were not detected in the juice samples, however, the juice had low $\left(1 \times 10^{5}-1.5 \times 10^{5} \log 10 \mathrm{cfu} / \mathrm{ml}\right)$ total viable count. Cashew-pawpaw juice blend prepared from $50 \%$ raw cashew juice and pawpaw puree was highly rated in terms of taste, colour, flavor and overall acceptance. In conclusion, acceptable low acid juice that is also rich in ascorbic acid can be produced from blend of raw cashew and pawpaw puree.

Keywords: Cashew juice; Pawpaw puree; Physicochemical properties; Steamed cashew; Vitamin C. 


\section{INTRODUCTION}

Fruits are important sources of nutrients (Ingweye and Akpan, 2014). They are not only nutritive but are also indispensable for health maintenance. They play important roles in the diet of most people in the tropics, providing essential minerals and vitamins, and adding colour, flavour and variety to people's diet (Ara et al., 2014). Fruit processing is an important agro-industrial activity which adds economic value to fruit, prevent waste and minimize postharvest losses, in addition to providing alternative uses for fruit. Cashew (Anacardium occidentale) is one of the commonly cultivated fruit trees in tropical region of the world.

Cashew tree is an economic crop in Africa including Nigeria. The tree produces nuts and cashew apples (which is a pseudo fruit). Cashew nuts has recently become an exportation crop in many African countries including Nigeria. Cashew apple is juicy with pleasant flavor, but some cultivars are acidic. In some countries, cashew apple is marketed as frozen pulp, nectar and juice (Marc et al., 2019). However, in Nigeria, the fruit is mostly consumed in the raw form.

Cashew fruits are considered good sources of micronutrients such as vitamins (thiamine, niacin, riboflavin, $\beta$-carotene (vitamin A precursor), antioxidants (carotenoids and phenolics) and macronutrients including reducing sugars and amino acids (Pascal et al., 2018). Vitamin C (ascorbic acid) content of cashew fruit $(34.61 \mathrm{mg} / 100 \mathrm{~g})$ is about half that of orange $(64.85 \mathrm{mg} / 100 \mathrm{~g})$ (Ernest et al., 2017). Cashew juice is also rich in mineral elements (calcium, sodium, magnesium, iron zinc, potassium, phosphorous and copper) (Lowor and Agyente-Badu, 2009).

Cashew fruit bruises easily and spoils quickly from bacteria action. This causes losses to cashew farmers and traders. In addition, cashew has unpleasant biting sensation on the tongue and throat when eaten raw. This is due to the astringency and acrid taste caused by the high composition of tannin in cashew fruits (Pascal et al., 2018). Thus, it is important to process cashew into fruit juice. However, cashew juice is also affected by its astringency and acidic nature. Studies have shown that the astringent component of cashew can be removed by pretreatment methods such as steaming, boiling in salt water and addition of gelatin to the juice extracts (Uma and Khasim, 2013; Prommajak et al., 2020). On the other hand, addition of other fruits such as pawpaw, orange 
(which are rich in vitamins and minerals) to cashew juice may also reduce acidity of the juice and increase its micronutrients composition.

Pawpaw, a member of Caricaceae family is called "Carica papaya L" scientifically. It is cultivated in America and African countries. Pawpaw fruit is rich in sugar, vitamin $\mathrm{C}, \beta$-carotene (vitamin $\mathrm{A}$ precursor), thiamin, riboflavin and Niacin (Pinnamaneni, 2017). Pawpaw fruits are also good sources of minerals (calcium, sodium, potassium, phosphorus and magnesium) which are beneficial to man (Chukwuka et al., 2013). Generally, pawpaw fruit belongs to the group of low acid fruits with pH ranging between 5.9 and 6.2 (Mudawia and Abdalatifb, 2017). The fruits have been used for making economically viable products such as jelly (Yi-zhuo et al., 2013), pickle and candied fruit, due to its mild flavor (Njoya et al., 2017). Blending of two or more tropical fruits for mixed fruit juice production has the potential of improving the nutritional composition and sensory attributes of the juice. According to Dauda (2014), mixed fruit juice produced from the blend of $70 \%$ pawpaw and 30\% African star apple had better sensory attributes than pure African star apple juice. In another study, ready-toserve beverage prepared from blend of cashew apple juice and pineapple juice had better acceptability than pure cashew juice (Sobhana et al., 2015). In addition, mixed fruit juice has been produced from blend of pawpaw and lime (Ameh et al., 2015), and blend of cashew apple, acerola, guava, papaya, and passion fruit (De Sousa et al., 2010). The aim of this study is to investigate the influence of cashew steaming on the physicochemical composition and consumers' acceptability of cashew-pawpaw juice blend.

\section{MATERIALS AND METHODS \\ Materials}

Fresh ripped Brazilian cashew and yellow flesh pawpaw fruits were harvested at Ladoke Akintola University of Technology (LAUTECH) Research farm, Ogbomoso, Oyo State, at their physiological maturity.

\section{Extraction of Cashew Juice and Pawpaw Puree}

Fresh ripped cashew and pawpaw fruits were separately washed, de-seeds, followed by juice extraction. This was done by hand squeezing the juice of fresh cashew and steamed cashew $\left(100^{\circ} \mathrm{C}, 10 \mathrm{~min}\right)$ into separate clean container. In the case of pawpaw, the puree was extracted by blending small pieces of pawpaw fruits in an electric blender for $3 \mathrm{~min}$. The juice blends were prepared according to the method described by Sobhana et al. (2015) with some 
modifications. Extracted cashew juice was filtered using muslin cloth to obtain smooth juice and pasteurized $\left(75^{\circ} \mathrm{C}\right.$ for $5 \mathrm{~min}$ ), cooled and filled into sterilized bottles. The pawpaw puree was also pasteurized $\left(75^{\circ} \mathrm{C}\right.$ for $\left.5 \mathrm{~min}\right)$, cooled and filled into sterilized bottles. The juice and puree were used to prepare the juice blend immediately.

\section{Preparation of cashew-pawpaw mixed juice}

Cashew-pawpaw mixed juice was produced by mixing varying proportions $(90: 10,80: 20,70: 30,60: 40,50: 50)$ of raw or steamed cashew juice and pawpaw puree. Fresh cashew juice was used as control.

\section{Physicochemical properties of the juice}

The $\mathrm{pH}$ and titratable acidity (TTA) of the juice were determined following the procedure described by Dauda (2014). The $\mathrm{pH}$ of the juice was measured using electronic $\mathrm{pH}$ meter, after its initial standardization to 4.0 and 7.0. TTA was determined by titrating $10 \mathrm{ml}$ of the juice sample against $0.1 \mathrm{~N} \mathrm{NaOH}$ to a pink end point using phenolphthalein indicator. The relative amount of total acidity of the juice was calculated as follows:

$\%$ Titratable acidity $=\underline{\text { Titre value } \times \text { Normality }} \times 100$

Weight of sample

The total solids and total soluble solid were determined following the procedure described by Dauda et al. (2016) and vitamin C contents of the juice were determined using the procedure described by Adetunji et al. (2013).

\section{Microbial Analysis}

All the juice samples were evaluated for total viable count (TVC), total yeast count (TYC) and total coliform (TCF) count after 3 days of storage in the refrigerator. The pour plate method described by De Sousa et al. (2010) was used for the TVC evaluation. TVC and TYC were done in duplicate using a colony counter after incubation at $37^{\circ} \mathrm{C}$ for $24 \mathrm{~h}$ (Ntuli et al., 2017).

\section{Sensory Evaluation}

The fruit juice samples were presented to 30 semi-trained panelists comprising of staff and undergraduate students of Ladoke Akintola University of Technology (LAUTECH). The panelist evaluated the juice samples based on taste, flavour, mouth-feel, colour, and overall acceptance. The samples were rated using nine-point hedonic scale, with 1 and 9 representing dislike extremely and like extremely, respectively. 


\section{Statistical analysis}

All experiments were performed in triplicates. Data obtained were subjected to analysis of variance (ANOVA) using Minitab statistic software (version 16).

Means were separated using Turkey's test and differences were determined at $\mathrm{P} \leq 0.05$.

\section{RESULTS AND DISCUSSION}

\section{Physicochemical Composition of Cashew-Pawpaw Juice}

The results of the physicochemical composition of the cashew-pawpaw juice prepared from raw and steamed cashew juice are presented in Table 1 and 2, respectively. The results showed that vitamin $\mathrm{C}$, total solids, total soluble solids and $\mathrm{pH}$ of the juice blend increases with increasing proportion of pawpaw puree in the blends. However, the titratable acidity (TTA) of the juice decreases with increasing pawpaw puree proportion in the blends. This could be due to high $\mathrm{pH}$ (6.3) of pawpaw juice.

Among all the fruit juice samples, juice blend containing 50\% raw cashew and $50 \%$ pawpaw fruit (sample R5) contained highest value of ascorbic acid (23.9 $\mathrm{mg} / 100 \mathrm{~g}$ ), followed by $50 \%$ steamed cashew-pawpaw juice blend (18.8 $\mathrm{mg} / 100 \mathrm{~g}$ ). This indicates that steaming of cashew has negative effect on ascorbic acid contents of the fruit, probably due to heat sensitivity of ascorbic acid. Higher ascorbic acid value recorded for sample containing $50 \%$ pawpaw juice compared to other samples could be due to high ascorbic acid contents of pawpaw juice $(68.7 \mathrm{mg} / 100 \mathrm{~g})$ (Table 1$)$. Ascorbic acid content of the $50 \%$ raw cashew-pawpaw fruit blend juice $(23.9 \mathrm{mg} / 100 \mathrm{~g})$ was higher than that of singlestrength orange juice $(17.19 \mathrm{mg} / 100 \mathrm{~g})$, similar to that of synthetic orange juice (24.56 mg/100g) (Brause et al., 2003), but slightly lower than that of commercially-available apple juice $(28.3 \mathrm{mg} / 100 \mathrm{~mL}$ ) (Abushusha \& Sayed, 2017). The findings of this study indicate that consumption of juice blend from $50 \%$ raw cashew and pawpaw puree will significantly increase ascorbic acid intake of the consumers.

Juice samples prepared from steamed cashew juice had lower TTA (0.17$0.35 \%)$ compared to the juice samples from raw cashew juice $(0.19-0.39 \%)$. This shows that acidity of cashew juice can be reduced by steaming. Previous study similarly reported that astringent and acrid taste of cashew can be reduced by steaming (Uma \& Khasim, 2013). In general, juice blend prepared 
from $50 \%$ raw and steamed cashew and pawpaw puree blend (i.e. sample R5 and S5) had lower acidity. Thus, these samples can be well tolerated by schoolage children and people suffering from ulcer ailment. In addition, juice blends prepared from steamed cashew juice had higher total solid (8.8-12.7\%) and total soluble solid (2.3-3.8\%) (Table 2) compared to total solid (8.0-12.4\%) and total soluble solid (1.4-3.5\%) of raw cashew juice blends (Table 1). This could be as a result of cashew juice concentration during steaming.

Addition of pawpaw to cashew juice increased the $\mathrm{pH}$ of the raw cashewpawpaw juice (3.70 - 4.65) and the steamed cashew-pawpaw juice (3.68 4.72). However, the $\mathrm{pH}$ value of the cashew-pawpaw mixed juice produced in this study is lower than the $\mathrm{pH}(4.06-5.09)$ of Tanzania cashew varieties (Mzoka et al., 2017). This could be due to varietal differences in cashew tree grown in Nigeria and Tanzania, and perhaps agronomic conditions.

Table 1: Physicochemical properties of raw cashew-pawpaw juice

\begin{tabular}{|c|c|c|c|c|c|}
\hline $\begin{array}{l}\text { Sample } \\
\text { code }\end{array}$ & $\begin{array}{l}\text { Ascorbic } \\
\text { Acid } \\
\text { (mg/100g) }\end{array}$ & $\begin{array}{c}\text { Titratable } \\
\text { Acidity (\%) }\end{array}$ & $\begin{array}{c}\text { Total solid } \\
\text { (\%) }\end{array}$ & $\begin{array}{c}\text { Soluble } \\
\text { solid } \\
\text { (\%) }\end{array}$ & $\mathrm{pH}$ \\
\hline $\mathbf{R}$ & $\begin{array}{c}10.20^{\mathrm{C}} \pm \\
0.79\end{array}$ & $0.39^{a} \pm 0.06$ & $8.03^{c} \pm 0.00$ & $\begin{array}{c}1.35^{\mathrm{c}} \pm \\
0.60\end{array}$ & $3.68^{c} \pm 0.36$ \\
\hline R1 & $\begin{array}{c}10.23^{c} \pm \\
0.64\end{array}$ & $0.37^{b} \pm 0.92$ & $8.94^{b} \pm 0.06$ & $1.51^{c} \pm 0.34$ & $3.70^{c} \pm 0.07$ \\
\hline $\mathbf{R 2}$ & $\begin{array}{c}12.50^{\mathrm{b}} \pm \\
0.00\end{array}$ & $0.34^{c} \pm 0.59$ & $9.73^{b} \pm 0.14$ & $2.50^{b} \pm 0.05$ & $\begin{array}{c}4.04^{b} \pm \\
0.15\end{array}$ \\
\hline R3 & $\begin{array}{c}22.80^{\mathrm{a}} \pm \\
0.28\end{array}$ & $0.27^{d} \pm 0.03$ & $11.21^{a} \pm 0.29$ & $2.84^{b} \pm 0.14$ & $\begin{array}{c}4.42^{\mathrm{a}} \pm \\
0.23\end{array}$ \\
\hline R4 & $\begin{array}{c}22.80^{\mathrm{a}} \pm \\
0.00\end{array}$ & $0.25^{d} \pm 0.07$ & $12.08^{a} \pm 0.11$ & $2.81^{b} \pm 0.09$ & $\begin{array}{c}4.53^{a_{ \pm}} \\
0.10\end{array}$ \\
\hline R5 & $\begin{array}{c}23.96^{\mathrm{a}} \pm \\
0.08\end{array}$ & $0.19^{\mathrm{e}} \pm 0.24$ & $12.37^{a} \pm 0.52$ & $3.53^{a} \pm 0.15$ & $\begin{array}{c}4.65^{\mathrm{a}_{ \pm}} \\
0.40\end{array}$ \\
\hline
\end{tabular}

Values are mean \pm standard deviation. Means with different superscript are significantly different $(p \leq 0.05)$. R - Raw cashew juice (100\%); R1 - Raw cashew-pawpaw juice at 90:10; R2 - Raw cashew-pawpaw juice at 80:20; R3 Raw cashew-pawpaw juice at 70:30; R4 - Raw cashew-pawpaw juice at 60:40; R5 - Raw cashew-pawpaw juice at 50:50. 


\section{Microbial Quality of the Cashew-Pawpaw Juice Blends}

Total yeast count and coliform count were absent in all the juice samples while low total viable count (TVC) was recorded. The TVC values ranges from $1 \times 10^{5}$ to $1.5 \times 10^{5} \log 10 \mathrm{cfu} / \mathrm{ml}$. These values are lower than the safe level of TVC (< $10^{6} \mathrm{cfu} / \mathrm{g}$ ) for ready-to-eat foods (CFS, 2014). These results indicate that the mixed fruit juice samples are wholesome and safe for consumption.

Table 2: Physicochemical properties of steamed cashew-pawpaw juice

\begin{tabular}{cccccc}
\hline $\begin{array}{c}\text { Sample } \\
\text { code }\end{array}$ & $\begin{array}{c}\text { Vitamin C } \\
(\mathbf{m g} / \mathbf{1 0 0 g})\end{array}$ & $\begin{array}{c}\text { Titratable } \\
\text { Acidity } \\
(\mathbf{m g} / \mathbf{1 0 0 m L})\end{array}$ & $\begin{array}{c}\text { Total solid } \\
(\%)\end{array}$ & $\begin{array}{c}\text { Soluble } \\
\text { solid } \\
(\%)\end{array}$ & $\mathbf{p H}$ \\
\hline S & $7.18^{\mathrm{c}} \pm 0.01$ & $0.35^{\mathrm{a}} \pm 0.66$ & $8.79^{\mathrm{c}} \pm 0.04$ & $2.3^{\mathrm{b}} \pm 0.24$ & $3.30^{\mathrm{c}} \pm 0.11$ \\
S1 & $9.41^{\mathrm{b}} \pm 0.64$ & $0.32^{\mathrm{a}} \pm 0.33$ & $8.99^{\mathrm{c}} \pm 0.00$ & $2.5^{\mathrm{b}} \pm 0.34$ & $3.68^{\mathrm{c}} \pm 0.07$ \\
S2 & $9.56^{\mathrm{b}} \pm 0.00$ & $0.29^{\mathrm{b}} \pm 0.07$ & $10.00^{\mathrm{b}} \pm 0.14$ & $2.7^{\mathrm{b}} \pm 0.05$ & $4.00^{\mathrm{b}} \pm 0.15$ \\
S3 & $17.24^{\mathrm{a}} \pm$ & $0.25^{\mathrm{b}} \pm 0.51$ & $10.95^{\mathrm{b}} \pm 0.07$ & $3.2^{\mathrm{a}} \pm 0.14$ & $4.15^{\mathrm{a}} \pm 0.23$ \\
& 0.28 & & & & \\
S4 & $17.68^{\mathrm{a}} \pm$ & $0.21^{\mathrm{bc}} \pm 0.00$ & $12.20^{\mathrm{a}} \pm 0.28$ & $3.5^{\mathrm{a}} \pm 0.09$ & $4.57^{\mathrm{a}} \pm 0.10$ \\
& 0.00 & & & & \\
S5 & $18.75^{\mathrm{a}} \pm$ & $0.17^{\mathrm{c}} \pm 0.06$ & $12.74^{\mathrm{a}} \pm 0.99$ & $3.8^{\mathrm{a}} \pm 0.15$ & $4.72^{\mathrm{a}} \pm 0.40$ \\
& 0.08 & & & & \\
\hline
\end{tabular}

Values are mean \pm standard deviation. Means with different superscript(s) are significantly different $(p \leq 0.05)$. S - Steamed cashew juice $(100 \%)$; $S 1$ Steamed cashew-pawpaw juice at 90:10; S2 - Steamed cashew-pawpaw juice at 80:20; S3 - Steamed cashew-pawpaw juice at 70:30; S4 - Steamed cashewpawpaw juice at 60:40; S5 - Steamed cashew-pawpaw juice at 50:50.

\section{Sensory Evaluation}

Results of the sensory evaluation showed that juice samples produced from steamed cashew juice had significantly $(p<0.05)$ lower ratings compared to fresh raw cashew juice and juice blend from fresh cashew juice (Table 3). Fresh cashew juice (100\% cashew) had the highest sensory score for taste (8.09), colour (7.36), flavour (6.91) and overall acceptance (7.09) among all the juice samples. This could probably be due to familiarity of the panelists with raw cashew fruit juice. However, among the juice blend samples, $50 \%$ raw cashew and pawpaw juice blend had the highest sensory score for taste (6.64), flavor (5.73) and overall acceptance (5.73). This could be because of the enrichment 
of cashew juice with pawpaw flavor and sweetness. On the other hand, all the juice blends were similarly rated in terms of colour. In general, juice sample from $50 \%$ raw cashew juice blend and $50 \%$ pawpaw was most preferred among the entire juice blends.

Table 3: Sensory evaluation of cashew-pawpaw juice

\begin{tabular}{ccccc}
\hline $\begin{array}{c}\text { Sample } \\
\text { code }\end{array}$ & Taste & Colour & Flavor & $\begin{array}{c}\text { Overall } \\
\text { acceptability }\end{array}$ \\
\hline R & $8.09^{\mathrm{a}} \pm 1.30$ & $7.36^{\mathrm{a}} \pm 1.92$ & $6.9^{\mathrm{a}} \pm 1.22$ & $7.09^{\mathrm{a}} \pm 1.51$ \\
R1 & $4.36^{\mathrm{d}} \pm 1.43$ & $5.27^{\mathrm{b}} \pm 1.95$ & $5.00^{\mathrm{b}} \pm 1.55$ & $5.09^{\mathrm{b}} \pm 1.14$ \\
R2 & $3.73^{\mathrm{e}} \pm 1.34$ & $5.64^{\mathrm{b}} \pm 1.21$ & $4.82^{\mathrm{b}} \pm 1.33$ & $4.63^{\mathrm{b}} \pm 1.29$ \\
R3 & $3.73^{\mathrm{e}} \pm 1.42$ & $5.64^{\mathrm{b}} \pm 0.92$ & $4.73^{\mathrm{b}} \pm 1.27$ & $4.91^{\mathrm{b}} \pm 0.94$ \\
R4 & $4.09^{\mathrm{d}} \pm 1.22$ & $5.46^{\mathrm{b}} \pm 1.29$ & $4.55^{\mathrm{b}} \pm 1.29$ & $4.82^{\mathrm{b}} \pm 1.08$ \\
R5 & $6.64^{\mathrm{b}} \pm 1.03$ & $5.82^{\mathrm{b}} \pm 0.75$ & $5.73^{\mathrm{b}} \pm 1.19$ & $5.73^{\mathrm{b}} \pm 1.10$ \\
S & $5.82^{\mathrm{c}} \pm 1.94$ & $5.82^{\mathrm{b}} \pm 1.25$ & $4.36^{\mathrm{b}} \pm 1.03$ & $4.64^{\mathrm{b}} \pm 0.81$ \\
S1 & $4.09^{\mathrm{d}} \pm 1.04$ & $5.46^{\mathrm{b}} \pm 1.29$ & $3.82^{\mathrm{c}} \pm 1.08$ & $4.27^{\mathrm{c}} \pm 1.10$ \\
S2 & $3.64^{\mathrm{e}} \pm 1.04$ & $5.36^{\mathrm{b}} \pm 1.29$ & $3.55^{\mathrm{c}} \pm 1.29$ & $4.27^{\mathrm{c}} \pm 1.62$ \\
S3 & $3.36^{\mathrm{e}} \pm 1.36$ & $5.00^{\mathrm{b}} \pm 1.67$ & $3.91^{\mathrm{c}} \pm 1.38$ & $4.82^{\mathrm{b}} \pm 1.41$ \\
S4 & $4.09^{\mathrm{d}} \pm 1.22$ & $5.36^{\mathrm{b}} \pm 1.63$ & $4.00^{\mathrm{bc}} \pm 1.34$ & $4.64^{\mathrm{b}} \pm 1.50$ \\
S5 & $5.00^{\mathrm{c}} \pm 1.41$ & $5.46^{\mathrm{b}} \pm 1.64$ & $4.00^{\mathrm{bc}} \pm 1.34$ & $4.91^{\mathrm{b}} \pm 1.02$
\end{tabular}

Values are mean \pm standard deviation. Means with different superscript(s) are significantly different $(p \leq 0.05)$. Sample codes are as defined in Table 1 and 2.

\section{CONCLUSION}

The findings of this study showed that addition of pawpaw puree to cashew juice enhanced the taste of the juice, and also increased its ascorbic acid (vitamin C) contents. Although steaming reduces the astringent and acidic taste of cashew juice, there was reduction in vitamin $C$ contents of the mixed fruit juice prepared from steamed cashew fruits. Cashew-pawpaw juice produced 
from $50 \%$ raw cashew and pawpaw puree had the highest physicochemical properties and sensory scores. In general, juice production from blend of cashew and pawpaw fruit will not only increase cashew fruit usage, but also improve vitamin $\mathrm{C}$ intake of consumers, and add varieties to commercially available juice products. Future studies should be done on optimization of steaming conditions for better vitamin $\mathrm{C}$ retention.

\section{REFERENCES}

Abushusha, W.M.A., and Sayed, S.F. (2017). Comparative Analysis of Vitamin C Content of Some Locally Available Packed and Fresh Fruit Juices by Redox Titration Method. International Journal of Advanced Research, 5(5), 1548-1554.

Adetunji, C.O., Fawole, O.B., Arowora, K.A., Nwaubani, S.I., Oloke, J.K., Adepoju, A.O., Adetunji, J.B., and Ajani, A.O. (2013). Performance of Edible Coatings from Carboxymethylcellulose $(\mathrm{Cmc})$ and Corn Starch $(\mathrm{Cs})$ Incorporated with Moringa Oleifera Extract on Citrus Sinensis. Agrosearch, 13(1), $77-85$.

Ameh, B.A., Gernah, D., Obioha, O., and Ekuli, G.K. (2015). Production, Quality Evaluation and Sensory Acceptability of Mixed Fruit Juice from Pawpaw and Lime. Food and Nutrition Sciences, 6, 532-537.

Ara, R., Jahan, S., Abdullah, A.T.M., Fakhruddin, A.N.M., and Saha, B.K. (2014). Physicochemical Properties and Mineral Content of Selected Tropical Fruits in Bangladesh. Bangladesh Journal of Scientific and Industrial Research, 49(3), 131-136.

Brause, A.R., Woollard, D.C., and Indyk, H.E. (2003). Products by Liquid Chromatography: Interlaboratory Study. Journal of AOAC International, 86(2), 367-374.

Centre for Food Safety (CFS) (2014). Microbiological guidelines for food: For ready-to-eat food in general and specific food items. Hong Kong: China.

Chukwuka, K.S, Iwuagwu, M and Uka, U.N. (2013). Evaluation of Nutritional Components of Carica papaya L. at Different Stages of Ripening. IOSR Journal of Pharmacy and Biological Sciences (IOSR-JPBS), 6(4), 1316. 
Dauda, A. O. (2014). Quality Attributes of Fruit Juices made from Blends of Indigenous Fruit (African Star Apple) With Conventional Fruit (Papaya). International Journal of Research in Agriculture and Food Sciences, 2(1), $16-20$.

Dauda, A.O., Abiodun, A.O., and Ibanga, U.I. (2016). Stability of Blend of Carrot, Pineapple and Soymilk Treated with Aframomum Danielli Powder. Agrosearch, 16(2), 1-6.

De Sousa, P.H.M., Maia, G.A., de Azeredo, H.M.C., Ramos, A.M., and de Figueiredo, R.W. (2010). Storage stability of a tropical fruit (cashew apple, acerola, papaya, guava and passion fruit) mixed nectar added caffeine. International Journal of Food Science and Technology, 45, 2162-2166.

Ernest, E., Onyeka, O., Ozuah, A. C., and Onwubiko R.O. (2017). Comparative Assessment of the Effect of Ripening Stage on the Vitamin C Contents of Selected Fruits Grown within Nsukka Axis of Enugu State. International Journal of Environment, Agriculture and Biotechnology, 2(2), 712 -714.

Ingweye, J.N. and Akpan, I.A. (2014). Examination of Vitamin and Amino Acid Profiles of Gmelina (Gmelina arborea) Fruit and Fruit Pulp. Agrosearch, 14(1), 14-23.

Sobhana, A., Mathew, J., AmbiliAppukutan, A., and MredhulaRaghavan, C. (2015). Blending of cashew apple juice with fruit juices and spices for improving nutritional quality and palatability. Acta Horticulturae, 1080, 369-375.

Lowor, S.T., and Agyente-Badu, C.K. (2009). Mineral and proximate composition of cashew Apple Juice from Northern Savannah, Forest and Costal Savannah Regions in Ghana. American Journal of Food Technology, 4, $154-161$.

Marc, A., Achille, T.F., Désiré, A.Y., and Georges, A.N. (2019). Stabilization and Sensory Evaluation of Cashew Apple Juice (Anacardium occidentale L.) from the Northeast Region in Côte d'Ivoire. Journal of Food Science Nutrition Research, 2 (2), 108-127.

Mudawia, H.A., and Abdalatifb, F.Y. (2017). Evaluation of Canned Pawpaw (Carica Papaya) and Guava (Psidium guajaval.) Fruits in Sudan. 
International Journal of Agriculture, Environment and Bioresearch, 2(4), 93-102.

Njoya, M.A., Nain, C.W., Mahbou, P.Y., Mendi, S.D., and Imele, H. (2017). Physicochemical and Sensory Properties of Pawpaw (Carica Papaya Linn) Flavoured Yoghurt. African Journal of Food, Agriculture, Nutrition and Development, 17(3), 12311 - 12342.

Ntuli, V., Chatanga, P., Kwiri, R., Gadaga, H.T., Gere, J., Matsepo, T., and Potloane, R.P. (2017). Microbiological quality of selected dried fruits and vegetables in Maseru, Lesotho. African Journal of Microbiological Research, 11(5), 185 - 193.

Pascal, A.D.C., Virginie, G., Diane, B.F.T., Estelle, K.R., Félicien, A., Valentin, W.D., and Dominique, S.K.C. (2018). Nutritional Profile and Chemical Composition of Juices of Two Cashew Apple Varieties of Benin. Chemistry Journal, 4(4), 91-96.

Pinnamaneni, R. (2017). Nutritional and Medicinal Value of Pawpaw (Carica Papaya Linn.)". World Journal of Pharmacy and Pharmaceutical Sciences, 6(8), 2559-2578.

Prommajak, T., Leksawasdi, N., and Rattanapanone, N. (2020). Tannins in Fruit Juices and their Removal. Chiang Mai University Journal of Natural Sciences, 9(1), $76-90$.

Uma, T. and shaik, K.B. (2013). Quality, spoilage and preservation of cashew apple juice. Journal of Food Science and Technology, 52(1), 54-62.

Yi-zhuo, L., Ling-wen, Z., and Qing-xin, W. (2013). Preparation of healthy papaya jelly. Food Science and Technology, 38(7), 133-136. 